

\section{Sumário}

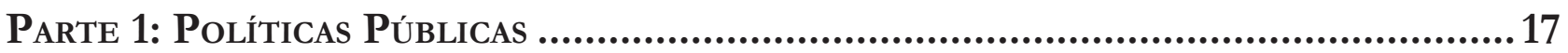

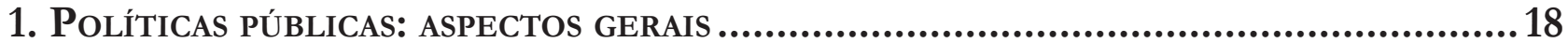

UM MODELO POLÍTICO DE IMPLEMENTAÇÃO PARA AS POLÍTICAS PÚBLICAS: OS PAPÉIS DO DIREITO E DOS JURISTAS.

William H. Clune III

Evaluación de las obras públicas en gobiernos locales en MÉxico: Desafíos de LaS POLÍTICAS PÚBLICAS DE PARTICIPACIÓN CIUDADANA

Louis Valentin Mballa e Arturo Bermúdez Lara

Paternalismo libertário e políticas públicas: intervenção e transparênCia

Marcia Carla Pereira Ribeiro e Victor Hugo Domingues

2. Políticas públicas E COVID-19

LiMITES E POSSIBILIDADES PARA O USO SECUNDÁRIO DE DADOS PESSOAIS NO PODER PÚBLICO: LIÇÕES DA PANDEMIA.

Miriam Wimmer

EFICIÊNCIA DAS POLÍTICAS DE INOVAÇÃO NOS SETORES INDUSTRIAIS BRASILEIROS: SUGESTÕES PARA A CRISE DA COVID-19

Michelle Márcia Viana Martins e Chrystian Soares Mendes

CoMPLIANCE EM TEMPOS DE CALAMIDADE PÚbLICA: ANÁLISE SOBRE A FLEXIBILIZAÇÃo DA TRANSPARÊNCIA DE DADOS E INFORMAÇÕES DURANTE O ENFRENTAMENTO DA COVID-19 NO BrasiL

Luciana Cristina da Conceição Lima, Alcindo Fernandes Gonçalves, Fernando Cardoso Fernandes Rei e Cláudio Benevenuto de Campos Lima

3. Políticas públicas e accountability

ACCOUNTABility E DESENHO INSTITUCIONAL: UM “PONTO CEGO" NO DIREITO PÚBLICO BRASILEIRO

Danielle Hanna Rached

ESTRATÉGIAS REGULATÓRIAS DE COMBATE À CORRUPÇÃo 
O controle e a avaliação pelo Tribunal de Contas da União das políticas públicas IMPLEMENTADAS POR DESONERAÇÕES TRIBUTÁRIAS NO BRASIL

Vinicius Garcia e Carlos Araújo Leonetti

4. Políticas públicas em Matéria de SAÚde

A livre opÇão pela Cesariana: um "NUdge Às aVessas". .268

Bruna Menezes Gomes da Silva e Júlio Cesar de Aguiar

AUTISMO: ASPECTOS JURÍDICOS DA ACESSIBILIDADE E RESPEITO

Fabiana Barrocas Alves Farah e Danilo Fontenele Sampaio Cunha

SAÚdE E DOENÇAS RARAS: ANÁLISE DA JUDICIALIZAÇÃo DO ACESSO AO TRATAMENTO E SUAS LIMITAÇÕES.

Danilo Henrique Nunes e Lucas de Souza Lehfeld

5. OUTRAS POLÍTICAS PÚBLICAS EM ESPÉCIE

REGUlAÇÃO DAS ÁGUAS: UMA ANÁLISE EMPÍRICA DA PRODUÇÃo NORMATIVA DOS ÓRGÃOS REGULADORES FEDERAIS

Bianca Borges Medeiros Pavão, Natasha Schmitt Caccia Salinas e Thauany do Nascimento Vigar

“LET THE ALGORITHM DECIDE": IS HUMAN DIGNITY AT STAKE?.

Marcela Mattiuzzo

DAS ACEPÇÕES DOS DIREITOS DOS REFUGIADOS ÀS VOZES SILENCIADAS NAS POLÍTICAS PÚBLICAs371 Thaís Araújo Dias e Monica Mota Tassigny

Planejamento familiar: “inimigo" a Ser combatido, “aliado” libertador ou falso "AMIGO"?

Vinicius Ferreira Baptista

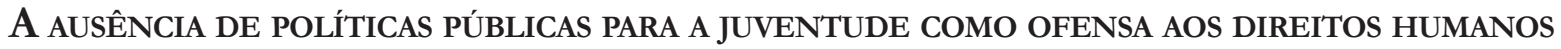
William Timóteo e llzver de Matos Oliveira

AnÁlise CÊniCa dos feminicídios em Curitiba: propostas preventivas e repressivas ....433 Ticiane Louise Santana Pereira, Octahydes Ballan Junior e Antonio Henrique Graciano Suxberger

ORIGIN AND CONSEQUENCES OF THE WAR ON DRUGS. FROM THE UNITED STATES TO ANDEAN COUNTRIES

Silvio Cuneo e Nicolás Oxman 
Trabalho Decente: comportamento Ético, política pública ou Bem JuRIDiCamente TUTELADO?.

Silvio Beltramelli Neto e Mônica Nogueira Rodrigues

El FINAL DE UNA POLÍtica PÚBLICA: ANÁLISIS DEL CICLO POLÍTICO DEL PROYECTO DESTINOS INDUCTORES PARA EL DESARROLLO TURISTICO REGIONAL (DIDTR) - BRASIL. .496

María Belén Zambrano Pontón, Magnus Luiz Emmendoerfer e Suely de Fátima Ramos Silveira

Alternativa tecnológica para COMPensaÇão de CRÉditos de ICMS: ESTUdo de Caso da VIABILIDADE DO USO DE DLT EM NOTA FISCAL ELETRÔNICA .520

Danielle Mendes Thame Denny, Roberto Ferreira Paulo e Fernando Crespo Queiroz Neves

Parte 2: Temas Gerais

A construção do Direito Humano ao Alimento no plano internacional. 551 Tatiana de A. F. R. Cardoso Squeff

Grupos vUlNERABles de ESPECIAL PROTECCIÓN POR PARTE DEL INSTITUTO NACIONAL DE Derechos Humanos (INDH) ¿EN QUIÉN PODRÍA Y DEBERÍA ENFOCARSE EN BASE A LA DOCTRINA Y A LA EXPERIENCIA COMPARADA IBEROAMERICANA?

Juan Pablo Díaz Fuenzalida

El SUFRAGIO ELECTRÓNICO COMO ALTERNATIVA AL SUFRAGIO TRADICIONAL: LUCES Y SOMBRAS DE UN DEBATE RECURRENTE 595

David Almagro Castro, Felipe Ignacio Paredes Paredes e Edgardo Lito Andres Cancino

Cognoscibilidade E CONTROLE SOCIAL dA TRANSPARÊNCIA PÚbliCA SOB A ÉGIDE DA DEMODIVERSIDADE: ESTUDO EMPÍRICO DE PORTAIS ELETRÔNICOS MINISTERIAIS LATINOAMERICANOS

Ana Carolina Campara Verdum, Leonardo Fontana Trevisan e Rosane Leal da Silva

DESAFIOS E BENEFÍCIOS DA INTELIGÊNCIA ARTIFICIAL PARA O DIREITO DO CONSUMIDOR 655 Sthéfano Bruno Santos Divino

QUEM TEM MEDO DA RESPONSABILIZAÇÃo SUBJETIVA? As TEORIAS DA CONDUTA E DA IMPUTAÇÃO, PARA UM DIREITO ADMINISTRATIVO SANCIONADOR CONSTITUCIONALIZADO...........................690 Sandro Lúcio Dezan e Paulo Afonso Cavichioli Carmona

A INSUfiCiÊNCIA dE TRIBUTAÇÃo COMO FUNDAMENTO PARA O AFASTAMENTO DA RESERVA DO POSSÍVEL NA GARANTIA DO MÍNIMO EXISTENCIAL E DA DIGNIDADE HUMANA. 711 Dione J. Wasilewski e Emerson Gabardo 


\title{
Compliance em tempos de calamidade pública: análise sobre a flexibilização da transparência de dados e informações durante o enfrentamento da COVID-19 no Brasil*
}

\author{
Compliance in times of public calamity: \\ analysis on the flexibilization of the \\ transparency of data and information during \\ COVID-19's facing in Brazil
}

* Recebido em 01/05/2020

Aprovado em 16/02/2020

** Doutora em Direito Ambiental Internacional pela Universidade Católica de Santos; Mestre em Sistemas de Gestão e Pós-Graduada em Organizações e Estratégia pela Universidade Federal Fluminense (UFF); Graduada em Direito pela Universidade Católica de Santos e em Pedagogia pela Universidade Federal de Minas Gerais (UFMG); Advogada, Auditora e Consultora em Sistemas de Gestão, Proteção de Dados e Compliance. E-mail: lulima@icloud.com

*** Doutor em Ciência Política pela USP; Mestre em Ciência Política pela USP; Graduado em Engenharia Civil pela USP; Coordenador do IPAT - Instituto de Pesquisas A Tribuna e Coordenador do Programa de Mestrado e Doutorado em Direito da Universidade Católica de Santos.

E-mail: alcindo@unisantos.br

**** Doutor em Direito Internacional pela USP e Doutor em Direito do Estado e Ambiental pela Universidad de Alicante; Doutor em Direitos Fundamentais - Universidad Complutense de Madrid; Mestre em Direito Comunitário pela Universidade de Coimbra; Graduado em Ciências Sociais e Jurídicas pela USP; Professor Titular de Direito Ambiental da Fundação Armando Álvares Penteado e Professor Assistente Doutor no Programa de Doutorado em Direito Ambiental Internacional da Universidade Católica de Santos. E-mail: fernandorei@ig.com.br

***** Doutor e Mestre em Sistemas de Gestão pela Universidade Federal Fluminense (UFF); Pós-Graduado em Organizações e Estratégia pela Universidade Federal Fluminense (UFF). Graduação em Engenharia Química Pela Universidade Federal de Minas Gerais (UFMG), Engenheiro de Petróleo pela Universidade Petrobras; Gerente da Gestão de Dados e Informações de Poços e de Eficiência Operacional da Construção de Poços Marítimos da Petrobras. E-mail:cbclima@hotmail.com
Luciana Cristina da Conceição Lima**

Alcindo Fernandes Gonçalves ${ }^{* * *}$

Fernando Cardoso Fernandes Rei****

Cláudio Benevenuto de Campos Lima*****

\section{Resumo}

A conformidade é de suma importância nas relações jurídicas da administração pública, que está adstrita ao Princípio da Legalidade, previsto na Constituição Federal do Brasil de 1988. Contudo, situações emergenciais permitem a mitigação dos efeitos de determinadas normas e procedimentos, que possam dificultar as ações de enfrentamento à crise. O presente artigo busca, por meio de pesquisa bibliográfica e estudo documental, analisar os impactos da decretação de calamidade pública no país, em razão da pandemia decorrente da doença causada pelo novo coronavírus (COVID-19), avaliando as consequências de possível flexibilização de procedimentos e regras, extremamente necessárias ao controle da gestão pública, como no caso das normas que tratam da transparência e do acesso à informação. Compreende-se que, para a manutenção de direitos e garantias fundamentais, bem como da transparência dos atos da gestão pública, ao revés da flexibilização das normas de controle, as situações excepcionais demandam a sua ampliação, para que a sociedade e autoridades possam acompanhar, ainda melhor, as atividades públicas, em virtude do aumento dos riscos de desvios, fraude e corrupção. Nesse sentido, pondera-se sobre a pertinência e importância da aplicação de programas de integridade na administração pública direta, que permitam a manutenção dos controles, de forma sistemática, mesmo em situações excepcionais. O presente trabalho se justifica pela necessidade de aprofundamento dos estudos relacionados à eficácia dos mecanismos de controle da gestão pública brasileira, bem como pela grande repercussão e interesse do tema no atual contexto de crise epidemiológica.

Palavras-chave: Compliance. COVID-19. Calamidade Pública. Pandemia. Acesso à Informação. Transparência. 


\section{Abstract}

Compliance has high importance in the legal relations of the public administration, which is subject to the principle of legality, provided for the Federal Constitution of Brazil of 1988. However, emergency situations allow the mitigation of the effects of certain rules and procedures, which may hinder actions facing the crisis. This article seeks, through bibliographic research and documentary study, to analyze the impacts of the decree of public calamity in the country, due to the pandemic caused by COVID-19, evaluating the consequences of possible flexibility of procedures and rules, extremely necessary to control management, as in the case of the ones dealing with transparency and access to information. It is understood that, in order to maintain fundamental rights and guarantees, as well as the transparency of public management acts, in spite of the flexibility of control rules, exceptional situations demand their expansion, so that society and authorities can follow, even better, public activities, due to the increased risk of diversion, fraud and corruption. In this sense, it is the case to think about the pertinence and importance of the application of integrity programs in the direct public administration, which allow the maintenance of controls, in a systematic way, even in exceptional situations. The present study is justified by the need to deepen studies related to the effectiveness of Brazilian public management control mechanisms, as well as by the great repercussion and interest of the theme in the current context of the epidemiological crisis.

Keywords: Compliance. COVID-19. Public Calamity. Pandemic. Information Access. Transparence.

\section{Introdução}

Em 20 de março de 2020, o Senado Federal aprovou o Decreto Legislativo n. ${ }^{\circ}$ 06, que reconheceu a ocorrência de calamidade pública no Brasil, nos termos requeridos pelo governo federal, através da Mensagem n. ${ }^{\circ}$ 93, de 18 de março de 20201. A referida mensagem foi formulada em razão da pandemia do novo coronavírus (COVID-19) ${ }^{2}$, decretada pela Organização Mundial da Saúde (OMS) ${ }^{3}$. O poder executivo federal enfatizou, no documento, a importância do reconhecimento de calamidade, em função das restrições de gastos determinados pela meta fiscal estabelecida para o ano de 2020 (teto de gastos) e da limitação de empenho estabelecida pelo art. $9^{\circ}$ da Lei Complementar n. ${ }^{\circ} 101$, de 4 de maio de 2000, também conhecida como Lei de Responsabilidade Fiscal (LRF), que dificultavam a realização, nesse cenário, de grandes investimentos na área da saúde pública, com consequências sociais e econômicas de maior complexidade.

A situação de calamidade pública foi reconhecida, com efeitos até 31 de dezembro de 2020, para atendimento do art. 65 da LRF, permitindo a suspensão temporária dos prazos para ajuste das despesas, do endividamento e do cumprimento das metas fiscais. Como consequência, foram facilitadas as contratações emergenciais, permitindo dispensar procedimentos e regras que pudessem causar atrasos e que prejudicas-

\footnotetext{
Mensagem n. ${ }^{\circ}$ 93, de 18 de março de 2020 em: https://legis.senado.leg.br/sdleg-getter/documento?dm=8075973\&ts=158635 9959498\&disposition=inline. Acesso em: 10 abr. 2020.

2 COVID-19 é a sigla utilizada pela Organização Mundial da Saúde (OMS) para denominar a doença respiratória, ocasionada pelo novo coronavírus da Síndrome Respiratória Aguda Grave (SARS-CoV-2) (LÓPEZ, Verónica et al. Recommendations on management of the SARS-CoV-2 coronavirus pandemic (COVID-19) in kidney transplant patients. Nefrologia (English Edition), in press, 2020). A sigla decorre de COrona VIrus Disease e o número 19 faz referência ao ano em que surgiram os primeiros casos. FIOCRUZ. Fundação Oswaldo Cruz. Por que a doença causada pelo novo vírus recebeu o nome de Covid-19? Disponível em: https://portal.fiocruz.br/pergunta/por-que-doenca-causada-pelo-novo-virus-recebeu-o-nome-de-covid-19. Acesso em: 10 abr. 2020. A doença foi identificada pela primeira vez em Wuhan, na província chinesa de Hubei, localizada na parte central do país. MACEDO JÚNIOR, Adriano Menino de. COVID-19: calamidade pública. Medicus, v. 2, n. 1, p. 1-6, 2020. A OMS declarou, em 30 de janeiro de 2020 , a COVID-19 como emergência de saúde pública de interesse internacional, com grande potencial para pandemia global, em razão do avanço e velocidade da propagação da doença LAI, Chih-Cheng et al. Severe acute respiratory syndrome coronavirus 2 SARSCoV-2) and corona virus disease-2019 (COVID-19): the epidemic and the challenges. International journal of antimicrobial agents, 2020). 3 QUINTÃO, Vinicius, et al. O Anestesiologista e a COVID-19. Brazilian Journal of Anesthesiology, in press, 2020.
} 
sem o processo de enfrentamento da pandemia que, por sua vez, demandava a imediata adoção de medidas que auxiliassem a população e o setor econômico, fortemente atingidos pela crise epidemiológica.

Nesse contexto, surgiram questões sobre a transparência das medidas e ações, tomadas durante o período de calamidade decretado. A flexibilização das normas e procedimentos também necessitava de controle sobre sua finalidade, legalidade, razoabilidade, eficiência e efetividade. A flexibilização, no caso, ocorreu para agilizar tomadas de decisão e impedir a responsabilização das autoridades, por terem de agir, em determinados casos, em desconformidade com leis, que regem o sistema em períodos de normalidade. A suspensão de determinadas normas oficiais buscou permitir agilidade e eficácia de medidas extremamente necessárias, que ocorrem em situações fortuitas, como no caso desta pandemia.

Por outro lado, a atividade pública continua devendo ser transparente, monitorável e aferível, justamente para demonstrar sua conformidade com as normas e princípios que permanecem vigentes. A transparência, publicidade e controle se tornam ainda mais importantes, principalmente porque situações de crise como esta envolvem certo grau de "afrouxamento" do rigor da contratação pública, implicando ações e tomada de decisões, que demandam maior fiscalização da sociedade e responsabilidade dos gestores públicos com princípios éticos para evitar a corrupção.

O presente estudo buscou demonstrar, por meio de pesquisa bibliográfica e estudo documental, a evolução das ações referentes ao coronavírus no país, até o momento da decretação de calamidade pública, para compreender os elementos que determinaram sua necessidade e finalidade. Em um segundo momento, foram analisados alguns aspectos relacionados às consequências da decretação de emergência e calamidade, incluindo alguns cases sobre ações de entes públicos, decorrentes das mitigações que a medida traz aos atos de gestão, instigando um olhar mais detido sobre os impactos a médio e longo prazos, em razão da possível flexibilização das regras de transparência sobre dados e informações.

Por fim, foi analisada a pertinência e importância da aplicação de programas de integridade na administração pública direta, que permitiam a manutenção dos controles, de forma harmônica e sistemática, ainda que ocorram situações que demandem certa mitigação de outras regras formais ou seus efeitos, por situação fortuita e excepcional. Conclui-se, então, pela indicação da aplicabilidade de programas de integridade na administração direta, por ser um mecanismo de controle adaptável a sistemas públicos e privados e difundidos mundialmente, por sua condição de alinhamento com normas internacionais consagradas de boa governança.

O fortalecimento do compliance $e^{4}$, sua estrutura e ferramentas de controle na administração pública direta surgiu como ferramenta que pode contribuir para solução ou mitigação de questões relacionadas a desvios e corrupção, decorrentes da necessidade de flexibilização de normas e regras, que dificultem contratações e aquisições públicas. No entanto, o sistema permite a manutenção da transparência e accountability, regras que não podem e não devem sofrer flexibilização. Compreende-se que, apesar do arrefecimento de determinadas leis nos casos de calamidade, o controle das ações públicas e de suas relações com a sociedade e, principalmente, com o setor privado, devem ser claras, acessíveis e monitoradas, de forma a permitir a avaliação da adequação das medidas ao interesse público, mesmo em tempos de calamidade. Nesse ponto, um bom programa de integridade e conformidade poderá contribuir para o monitoramento das ações de forma global, ainda que as regras de rotina necessitem de mudanças pontuais e transitórias.

\footnotetext{
4 Compliance é um termo em inglês relacionado à conformidade e cumprimento de normas, princípios, regras e obrigações, que podem ser de natureza legal e/ou voluntária, aquelas que a organização assume voluntariamente e incorpora em sua gestão TEIJEIRA RODRÍGUEZ, Mariano. Responsabilidad social corporativa y compliance legal (autorregulación y control interno). In: DERECHO administrativo del medio ambiente: Temas y prácticas de actualidad jurídica. Servicio de Publicaciones de la Facultad de Derecho, 2018. p. 219-240. Nesse sentido, a expressão compliance acaba sendo comumente adotada para se referir ao comportamento esperado perante normas e padrões previamente estabelecidos, bem como o respeito às questões éticas e morais, que possam contribuir ao combate à corrupção.
} 


\section{Situação de calamidade em tempos de pandemia: necessidade de ação do estado versus responsabilização jurídica}

A Constituição Federal do Brasil, de 1988, em seu Título V, Capítulo I, Artigo 136, prevê a possibilidade de determinação de Estado de Defesa e Estado de Sítio em casos de calamidade, que ameacem a ordem pública, a paz social e que possam gerar instabilidade institucional. Essas medidas são decretadas em situações extremas, por um período determinado e exíguo, por permitirem restrições a determinados direitos e garantias fundamentais, que podem estar sujeitos a limitações, em razão de colisão com outros diretos também fundamentais 5 .

No caso do Estado de sítio, a Constituição dispõe, expressamente, em seu Artigo 139, inciso III, sobre a possibilidade de o Poder Executivo impor sigilo sobre as comunicações e restrições sobre à prestação de informações, dentre outras medidas. No entanto, a Carta Magna estabelece, no dispositivo seguinte, Artigo 140, controles necessários sobre as medidas determinadas nesse período. Neste caso, é dado ao Congresso Nacional, por meio de uma Comissão por ele instituída, o dever de fiscalizar as medidas adotadas pelo Executivo em momento de crise.

A calamidade pública, por sua vez, é considerada pela Constituição Federal como um fenômeno, a partir do qual poderão ocorrer diversas outras consequências, como a instituição de empréstimo compulsório, a abertura de crédito extraordinário e, inclusive, a decretação dos Estados de Defesa e de Sítio. Apesar de se empregar comumente o termo "estado de calamidade", verifica-se que se trata de uma situação e não de um "estado" instituído nos moldes dos de Defesa e de Sítio, que possuem dispositivos e regras próprias a serem seguidos. A calamidade deve ser vista como um fato gerador para a adoção de outras medidas e políticas públicas excepcionais. Dessa forma, para melhor compreensão do termo, entende-se que o emprego de "estado" busca caracterizar uma determinada circunstância grave em que se encontra o país e não um instituto semelhante aos Estados de Defesa e de Sítio, que, por sua vez, demandam a ocorrência de emergências ou de calamidades no território nacional para sua efetivação.

O coronavírus foi relatado, pela primeira vez, em dezembro de 2019, em Wuhan, na província chinesa de Hubei, sendo consequentemente propagando para outras regiões da China e do mundo, "tornando-se gradualmente uma pandemia global”, declarada efetivamente pela OMS, em 11 de março de $2020^{7}$. Os primeiros casos de infectados no Brasil surgiram em fevereiro de $2020^{8}$ e a primeira morte foi oficialmente relatada em 17 de março do mesmo ano9. Antes disso, em 4 de fevereiro de 2020, o Ministério da Saúde, por meio da Portaria n. ${ }^{\circ}$ 188/2020, declarou emergência em saúde pública de importância nacional, consideran-

\footnotetext{
MOURA, Emerson Affonso da Costa. Transparência administrativa, lei federal n. ${ }^{\circ}$ 12.527/2011 e sigilo dos documentos públicos: a inconstitucionalidade das restrições ao acesso à informação. Braz̨ilian Journal of Public Policy, v. 6, n. 2, p. 37, 2016.

6 A Organização Mundial da Saúde (OMS), em 30 de janeiro de 2020, declarou emergência de importância global, através de um comunicado de Emergência de Saúde de Preocupação Internacional (PHEIC), em razão dos números alarmantes de casos na China, da constatação de transmissão entre humanos e do início de propagação da doença para fora da China WHO. WHO Timeline - COVID-19. 2020. Disponível em: https://www.who.int/news-room/detail/08-04-2020-who-timeline---COVID-19. Acesso em: 10 abr. 2020. Apesar de o problema, no momento da declaração, estar basicamente localizado na China, a OMS entendeu que a questão era de repercussão global e que as ações deviam ser coordenadas, "com objetivos estratégicos de saúde pública para reduzir o impacto na saúde e na economia global. ALI, Shajeea Arshad et al. The outbreak of Coronavirus Disease 2019 (COVID-19)—An emerging global health threat. Journal of Infection and Public Health, 2020. A partir do momento em que o vírus começou a se espalhar mundialmente, atingindo, ao final do mês, mais de 170 países, a OMS, em 11 de março de 2020, tomou a decisão de declarar estado de pandemia global SHAW, Rajib; KIM, Yong-kyun; HUA, Jinling. Governance, technology and citizen behavior in pandemic: Lessons from COVID-19 in East Asia. Progress in Disaster Science, p. 100090, 2020.

SHAW, Rajib; KIM, Yong-kyun; HUA, Jinling. Governance, technology and citizen behavior in pandemic: Lessons from COVID-19 in East Asia. Progress in Disaster Science, p. 100090, 2020.

8 RODRIGUEZ-MORALES, Alfonso J. et al. COVID-19 in Latin America: The implications of the first confirmed case in Brazil. Trav Med Infect Dis, v. 101613, 2020.

9 BRASIL. Ministério da Saúde. Coronavirus: 1 morte e 291 casos confirmados. Disponível em: https://www.saude.gov.br/noticias/agencia-saude/46552-coronavirus-1-morte-e-291-casos-confirmados. Acesso em: 10 abr. 2020.
} 
do as ações e recomendações da OMS sobre o risco de disseminação do vírus pelo país e para evitar que um surto da doença pudesse colapsar o sistema da saúde pública.

Em ato contínuo, o Poder Executivo sancionou a Lei n. ${ }^{\circ}$ 13.979/2020, que estabelece sobre medidas para enfrentamento da emergência de saúde pública de importância internacional declarada. Em março de 2020, por meio do Decreto Legislativo n. ${ }^{\circ} 06$ de 2020, foi reconhecida a situação de calamidade pública no Brasil, em razão da pandemia da COVID-19, que tem afetado o mundo de forma dramática. A LRF, em seu Art. 65, prevê a possibilidade de reconhecimento de calamidade pública, para efeito da aplicação da Lei, desde que reconhecido pelo Congresso Nacional.

A declaração de situação de emergência, em nível internacional, foi considerada pela OMS ${ }^{10}$ como um alerta para que os países se preparassem para o risco de propagação internacional da doença, criando mecanismos coordenados de controle e respostas, diante de um muito provável cenário de contaminação em massa. Em nível nacional, as situações de emergência já permitem à administração pública e seus órgãos, por meio da Lei de Licitações 8.666/93, maior flexibilização na gestão de compras, contratações e tomada de decisões, de forma a facilitar a preparação e prevenção de situações extraordinárias. A diferença entre emergência e calamidade é que a primeira poderá perdurar por tempo indeterminado. Já no caso de reconhecimento de situação de calamidade, o prazo deve ser determinado, como foi estabelecido no Decreto Legislativo n. ${ }^{\circ}$ 06/2020. A medida visa, fundamentalmente, fornecer maior autonomia ao gestor público e agilidade nos procedimentos, para concretizar as medidas necessárias na prevenção e redução dos riscos e impactos decorrentes do evento extraordinário, que acometeu o país e suas regiões.

A flexibilização poderá prever a dispensa da observância de determinadas regras contidas em instrumentos normativos, como no caso da LRF e da Lei n. ${ }^{\circ}$ 8.666, de 21 de junho de 1993, que trata sobre de licitações públicas. No entanto, a referida flexibilização sobre o atendimento de determinados procedimentos normativos, em situações emergenciais e fortuitas, não exime a autoridade pública de responsabilidades, decorrentes do mau gerenciamento ou de improbidade administrativa. Importante lembrar que o objetivo da transigência legal é o atendimento mais ágil e eficaz do interesse público que, naquele momento, referia-se ao socorro às vítimas atingidas. Portanto, diante das normas que regem o Direito Administrativo, não se verifica a possibilidade de suspensão das regras de probidade, transparência, conformidade e ética.

Normas, como a Lei Complementar n. ${ }^{\circ}$ 131, de 26 de maio de 2009 (Lei da Transparência), que modifica a Lei Complementar n. ${ }^{\circ}$ 101/2000 (LRF), determinam que o gestor público deve disponibilizar, imediata e detalhadamente, informações sobre a execução orçamentária e financeira do ente federativo pelo qual é responsável. Não se verifica, nesse caso, qualquer complacência no que se refere ao dever de transparência e publicidade de informações de interesse público, devendo o gestor, segundo a Lei, garantir pleno conhecimento e acompanhamento da sociedade de todos os atos dos agentes administrativos, de forma a controlar sua legitimidade e eficiência ${ }^{11}$. O ato administrativo, portanto, deve ser sempre público, atendendo às restrições impostas pelos princípios da legalidade, finalidade e moralidade, sob pena de nulidade e de responsabi-

\footnotetext{
10 O Regulamento Sanitário Internacional (RSI) de 2005, instrumento jurídico internacional vinculante para 196 países, considerando os estados membros da Organização Mundial da Saúde (OMS), prevê estágios de alertas, que buscam ajudar os países a prevenirem e responderem aos riscos de saúde pública internacional e que ameacem a comunidade global de forma generalizada WHO. World Health Organization et al. Reglamento sanitario internacional. $2^{\mathrm{a}}$ edición. Ginebra: Organización Mundial de la Salud, 2008. Disponível em: https://apps.who.int/iris/bitstream/handle/10665/43983/9789243580418_spa.pdf?sequence=1. Acesso em: 13 abr. 2020. No caso do coronavírus, a OMS iniciou em estágios de alerta mais brandos, como risco alto e muito alto, considerando a evolução da gravidade e expansão da epidemia na região da China e em outros países. A decisão sobre a declaração de emergência internacional ocorreu a partir da constatação de que o evento se tornou um risco global, demandando ações coordenadas para seu controle DOMINGUEZ, Bruno. Alerta global: novo coronavírus é a sexta emergência em saúde pública de importância internacional declarada pela OMS. RADIS: Comunicação e Saúde, n. 210, p.14-21, 2020.

11 MOURA, Emerson Affonso da Costa. Transparência administrativa, lei federal n. ${ }^{\circ}$ 12.527/2011 e sigilo dos documentos públicos: a inconstitucionalidade das restrições ao acesso à informação. Brazilian Journal of Public Policy, v. 6, n. 2, p. $37,2016$.
} 
lização, inclusive criminal ${ }^{12}$, da autoridade que o editou ${ }^{13}$.

A Lei n. ${ }^{\circ}$ 12.527, de 18 de novembro de 2011, Lei de Acesso à Informação (LAI), também impõe à administração pública federal, estadual e municipal e seus órgãos a obrigação no atendimento às solicitações sobre informações e documentos relativos aos atos da gestão pública, trazendo responsabilização, inclusive de improbidade administrativa, prevista no $\$ 2^{\circ}$ do Artigo 32 da Lei. A norma traz, no entanto, a previsão sobre situações extraordinárias, que impeçam o agente público de fornecer a informação nos moldes previstos, cautelando a possibilidade de prorrogação do prazo, perante justificativas, conforme se depreende do $\$ 2^{\circ}$ do Artigo 10, da LAI. Em momento algum, a norma versa sobre a possibilidade de restrição da transparência dos dados e informações, bem como a suspensão do acesso durante períodos críticos.

De acordo com a Mensagem n. ${ }^{\circ}$ 93, emitida pelo governo federal, o pedido de decretação de calamidade pública pelo Congresso Nacional possui o objetivo de garantir a não responsabilização do Poder Executivo pelo desatendimento das regras contidas na LRF. A lei prevê, em seu art. 65, a suspensão da contagem dos prazos e das disposições estabelecidas nos artigos 23,31 e 70, bem como a "dispensa do atingimento dos resultados fiscais e a limitação de empenho prevista no art. $9^{\circ ”}$.

O governo federal demonstrou preocupação com futura responsabilização fiscal, que poderia culminar no impeachment ${ }^{14}$ do Presidente da República, como ocorreu, em 2016, com a Presidente Dilma Rousseff, que foi condenada pelo Congresso Nacional, por ter tangenciado as metas fiscais (pedaladas fiscais) ${ }^{15}$, não cumprindo, portanto, com as regras estabelecidas na LRF e cometendo infração político-administrativa, denominada como crime de responsabilidade ${ }^{16}$.

Dessa forma, a decretação de situação de calamidade pelo Congresso Nacional buscou garantir, em certa medida, tranquilidade ao gestor público para a tomada de decisões sobre investimentos necessários à saúde e economia do país, no período da pandemia. Por outro lado, torna-se importante salientar que as regras e princípios basilares, que regem a probidade administrativa, permanecem vigentes e não são suspensos em períodos de crise como este, podendo a sua não observância acarretar responsabilização jurídica, com consequente perda de mandato público. A própria LRF, em seu art. $1^{\circ}, \$ 1^{\circ}$, deixa clara a necessidade de que os atos administrativos sejam transparentes e disponíveis. Em nenhum momento, esse critério se torna balizado ou suspenso, em função da decretação de situação de emergência ou de calamidade pública. A transparência, controle e fiscalização são previstos, ainda, no Capítulo IX da referida Lei, determinando, sem ressalvas, que todos os atos sejam devidamente controlados.

\footnotetext{
12 KHAIR, Amir Antônio. Lei de responsabilidade fiscal: guia de orientação para as prefeituras. Brasília: Ministério do Planejamento, Orçamento e Gestão; BNDES, 2000. p. 05.

13 DI PIETRO, Maria Sylvia Zanella. Direito Administrativo. 26. ed. São Paulo: Atlas, 2013. p. 63.

14 O termo 'impeachment' é originário da Grã-Bretanha e trata de expressão dada ao processo de apuração e julgamento de crime de responsabilidade do Presidente da República, podendo culminar ou não na sua destituição e afastamento do cargo. O processo de impeachment é um mecanismo previsto no Brasil, desde a Constituição Federal de 1891, sendo processado e julgado pelo Congresso Nacional, apresentando-se como "um mecanismo do Legislativo para controlar os membros do Executivo" SERRANO, Pedro Estevam Alves Pinto. Dos requisitos jurídicos para a instauração do processo de impeachment do Presidente da República. Revista de Investigações Constitucionais, v. 2, n. 2, p. 189-213, 2015.

15 Pedalada Fiscal é um termo comumente usado para descrever um procedimento contábil realizado pelo governo, que postergava o pagamento de dívidas aos bancos, que, por sua vez, mantinham o financiamento de programas sociais. Esse procedimento foi considerado pelos técnicos do Tribunal de Contas da União (TCU) como operação irregular, que feria a Lei de Responsabilidade Fiscal. SALES, Tainah. Aspectos Jurídicos Do Impeachment, Dos Crimes De Responsabilidade E Das "Pedaladas Fiscais". Revista de Direito Brasileira, v. 16, n. 7, p. 57-78, 2017.

16 SERRANO, Pedro Estevam Alves Pinto. Dos requisitos jurídicos para a instauração do processo de impeachment do Presidente da República. Revista de Investigaçôes Constitucionais, v. 2, n. 2, p. 189-213, 2015.
} 


\section{Flexibilização das regras sobre transparência das informações e dados: impactos sobre a avaliação da conformidade legal e efetividade das medidas implementadas pela administração pública durante a pandemia do COVID-19.}

Os princípios da transparência e publicidade, previstos no Artigo 37 da Constituição Federal, são pilares que estruturam a administração pública. É a partir da LRF que surgem mecanismos para a efetivação desses pilares $^{17}$. A Lei de Responsabilidade Fiscal, em seu artigo $1^{\circ}$, trata da importância do planejamento e da transparência para reduzir riscos e tratar desvios e questões, que possam desequilibrar as contas fiscais. Ou seja, a Lei coloca a transparência como uma ferramenta fundamental para o sucesso da governança pública, que "exige uma abordagem holística e integrada" ${ }^{18}$ para seu efetivo cumprimento. A Lei n. 12.527/2011, por sua vez, fornece suporte aos princípios da publicidade e transparência, por meio da garantia do acesso à informação, elemento essencial e "necessário ao controle da administração pública"19, dispondo de dois mecanismos que garantem tanto a disponibilização periódica da informação (transparência ativa), quanto o canal para acesso à ela (transparência passiva) ${ }^{20}$.

A mitigação de normas, como as que estabelecem amplo acesso à informação pública, deve se dar em casos extremos e excepcionais, respeitando, todavia, princípios e regras fundamentais, que anteveem tal possibilidade. A transigência de algumas normas e procedimentos em situações emergenciais e/ou de calamidade pública, muitas vezes, torna-se necessária para facilitar a tomada de decisão na prevenção, no atendimento das vítimas e nos processos de resposta e recuperação ${ }^{21}$. Por outro lado, há a preocupação do gestor público com o cumprimento das normas previamente estabelecidas e com a responsabilização que o não atendimento a elas possa acarretar. Dessa forma, surge a discussão sobre a melhor forma de flexibilização das regras que, apesar das circunstâncias de crise, deve sempre ser avaliada, respaldada e monitorada pelos órgãos de controle e demais poderes (legislativo e judiciário), assim como pela sociedade, de forma a garantir a não violação de outros direitos fundamentais, como o direito à informação.

Um exemplo que demonstra a importância do controle e fiscalização da transparência das informações, durante períodos de decretação de calamidade, foi a tentativa do governo federal em suspender, através da Medida Provisória MP n. ${ }^{\circ}$ 928/202022, os prazos da Lei de Acesso à Informação. A referida MP incluiu o Artigo 6 ${ }^{\circ}-\mathrm{B}$ na Lei n. ${ }^{\circ}$ 13.979/2020, que dispõe sobre as medidas necessárias ao enfrentamento da COVID-19. A justificativa foi de que, em razão da necessidade de isolamento social, recomendado pelo Ministério da Saúde, servidores, em regime de quarentena ou teletrabalho e aqueles envolvidos diretamente no enfrentamento da emergência, teriam dificuldades em atender às solicitações sobre informações, documentos e dados solicitados aos órgãos competentes.

\footnotetext{
LEITE FILHO, Geraldo Alemandro; COLARES, André Felipe Vieira; ANDRADE, Izabela Cristina Fonseca. Transparência da gestão fiscal pública: um estudo a partir dos portais eletrônicos dos maiores municípios do Estado de Minas Gerais. Contabilidade Vista \& Revista, v. 26, n. 2, p. 114-136, 2015.

18 BARRETT, Pat. Achieving better practice corporate governance in the public sector. Australian National Audit Office, 2002. 19 MOURA, Emerson Affonso da Costa. Transparência administrativa, lei federal n. ${ }^{\circ} 12.527 / 2011$ e sigilo dos documentos públicos: a inconstitucionalidade das restrições ao acesso à informação. Braz̧ilian Journal of Public Policy, v. 6, n. 2, p. $37,2016$.

20 MIRANDA, Wallace Vieira de; ZAGANELLI, Juliana Costa. Marco civil da internet e política pública de transparência: uma análise da e-democracia e do compliance público. Revista Brasileira de Políticas Públicas, v. 7, n. 3, p. 633-646, 2018.

21 FREITAS, Carlos Machado de et al. Fortalecimento das capacidades de prontidão e resposta frente a situações de emergência de interesse de saúde pública: região nordeste. Rio de Janeiro: CEPEDES/FIOCRUZ, 2013. 34 p. Relatório de pesquisa, 2013.

22 A MP n. ${ }^{\circ} 928 / 2020$ altera a Lei n. ${ }^{\circ} 13.979$ de 6 de fevereiro de 2020 e dispõe sobre as medidas para enfrentamento da emergência de saúde pública de importância internacional, decorrente do coronavírus, estabelecendo restrições aos pedidos de acesso à informação, realizados aos órgãos públicos, seus agentes e servidores sujeitos ao regime de teletrabalho ou situação de quarentena. Suspende prazos de processos administrativos e prescricionais, previstos na legislação aplicável ao setor público. A MP 928/2020 também revoga o art. 18 da MP 927, que tratava da possibilidade de suspensão dos contratos de trabalho no período da pandemia Disponível em: http://www.planalto.gov.br/ccivil_03/_Ato2019-2022/2020/Mpv/mpv928.htm. Acesso em: 10 abr. 2020.
} 
Em momento de crise, o acesso à informação é imprescindível. Os atos de gestão, seus dados e documentos devem estar sempre disponíveis, respeitando e aplacando as dificuldades que o momento de força maior possa causar. Mesmo que haja necessidade de mitigação dos efeitos da lei, deve-se respeitar o devido procedimento legal. Assim, antes mesmo da análise da matéria sobre a necessidade de suspensão das regras contidas na LAI e de seus efeitos, verifica-se manifesto vício formal da MP 928/20. O ato do Poder Executivo buscou interferir, substancialmente, em matéria disposta no Art. 37 da Constituição Federal, que estabelece a obrigação da administração pública em obedecer ao princípio da legalidade e publicidade, dentre outros. Essa norma foi incluída na Constituição, por meio da Emenda Constitucional n. ${ }^{0} 19$ de 1998. Portanto, está amparada pela regra contida no art. 246, que proíbe, expressamente, a adoção de Medida Provisória para regulamentar matéria tratada por Emenda Constitucional (EC), editada entre 1995 até a data

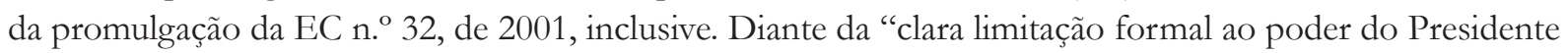
da República em editar normas com força de lei”23, identifica-se flagrante inconstitucionalidade das regras abordadas na Medida Provisória em análise, considerando, ainda, que os Artigo 5º inciso XXXIII, Artigo 37 e inciso II do $\int 3^{\circ}$ do mesmo dispositivo, bem como Artigo 216, $\int 2^{\circ}$ da Constituição, que tratam, especificamente, do direito de acesso à informação, encontram-se efetivamente regulamentados pela Lei de Acesso à Informação n. ${ }^{\circ} 12.527 / 11$.

No âmbito do vício material, a MP acaba excepcionando a regra trazida pela LAI, referente ao direito à informação dos atos da gestão pública e da transparência prevista na Lei Complementar n. ${ }^{\circ} 131$ de 2009, Lei da Transparência. A transparência e publicidade são garantias previstas pelo Art. $5^{\circ}$, inciso XXXIII da Constituição Federal. Ademais, compreende-se que, em situações de emergência e crise, a divulgação das informações deve funcionar de forma plena, mais ágil e precisa, para que a sociedade possa ter a garantia de que as decisões são acompanhadas e devidamente controladas. Em períodos críticos e incomuns, como esse de combate à pandemia da COVID-19, deve-se ampliar a transparência na atuação da administração pública, principalmente sobre aqueles referentes aos gastos e contratações excepcionais, em um cenário de pandemia, que foge à experiência dos gestores públicos, circunstância que demanda maior observação e controle sobre os riscos.

Especialistas e entidades, como a Associação Brasileira de Jornalismo Investigativo (Abraji) e a Ordem dos Advogados do Brasil (OAB), reagiram prontamente, questionando a finalidade e constitucionalidade da medida que, por sua vez, ainda não foi aprovada pelo Congresso Nacional. O economista Gil Castelo Branco, da Organização Não Governamental (ONG) Contas Abertas, alertou para o risco sobre a falta de transparência nesse momento importante de combate à COVID-1924. Em Ação Direta de Inconstitucionalidade (ADI) n. ${ }^{\circ}$ 6.351, a OAB alegou inconstitucionalidade formal ao afrontar a separação dos poderes legislativo e executivo na edição da Medida Provisória, bem como inconstitucionalidade material ao limitar o direito de informação, transparência e publicidade. A MP n. ${ }^{\circ}$ 928/2020, além de suspender os prazos para resposta, também previu a suspensão temporária do direito às reclamações e recursos nos casos em que houver recusa no atendimento das solicitações dos interessados, acabando, inclusive, com a necessidade de justificativa para a negativa, o que torna a medida "equivocada e desproporcional"25. A OAB salienta, ainda, que a LAI já possui dispositivo que contempla cenários de emergência e crise, não justificando a edição de uma MP sobre a matéria.

O Ministro do Supremo Tribunal Federal (STF), Alexandre de Moraes, em decisão liminar, suspendeu os efeitos do Artigo 6º-B da Lei n. ${ }^{\circ}$ 13.979/2020, sob o fundamento de que o dispositivo buscava transformar

\footnotetext{
23 ATAÍDE, Pedro. A (im) possibilidade de medida provisória na regulamentação de atividade minerária. Unisul de Fato e de Direito: Revista Jurídica da Universidade do Sul de Santa Catarina, v. 9, n. 16, p. 37-46, 2018.

24 https://congressoemfoco.uol.com.br/especial/noticias/entidades-reagem-a-suspensao-de-prazos-da-lei-de-acesso-a-informacao/. Acesso em: 12 abr. 2020.

25 Estadão. Equivocada e desproporcional': especialistas em dados abertos criticam medida de Bolsonaro que suspende Lei de Acesso à Informação. Disponível em: https://politica.estadao.com.br/blogs/fausto-macedo/equivocada-e-desproporcional-especialistas-criticam-medida-de-bolsonaro-que-suspende-prazo-da-lei-de-acesso-a-informacao/. Acesso em: 12 abr. 2020.
} 
em regra a exceção do sigilo à informação, quando afasta os princípios constitucionais de transparência e publicidade dos atos administrativos. De acordo com o Ministro, o acesso à informação somente poderá ser excepcionado quando houver interesse público e o artigo impugnado não apresenta qualquer situação excepcional, que justifique a medida. O STF decidiu, por unanimidade, no julgamento das ADIs n. ${ }^{\circ}$ 6.351, 6.347 e 6.353, referendando a decisão liminar proferida, mantendo, portanto, seus efeitos. Os demais Ministros entenderam não haver necessidade da restrição imposta pelo Artigo 6º-B da Lei n. ${ }^{\circ}$ 13.979/2020. De acordo com a decisão, o Estado está adstrito ao Princípio da Transparência e da Publicidade, devendo atender, conforme determinado pela Constituição Federal e Lei de Acesso à Informação, todas solicitações realizadas pela sociedade, salvo as hipóteses de sigilo, sob pena de responsabilização. Segundo o Relator, não há situação que justifique a restrição da transparência e publicidade dos dados e documentos, referentes aos atos da gestão pública nesse período. Argumenta, ainda, que a medida demonstra, em verdade, o interesse em dificultar o acesso livre às informações. Dessa forma, a Corte reconheceu que o acesso à informação é um direito fundamental dos cidadãos brasileiros e que não pode ser restringido sob o pretexto de uma crise epidêmica. Ademais, em Voto-Vogal Conjunto, o Ministro Gilmar Mendes salientou que a negativa de informações, além de dificultar o controle social, dá margem a práticas não democráticas.

A Medida Provisória n. ${ }^{\circ}$ 928/20, além de suspender os prazos para atendimento das solicitações, retira do interessado direitos e prerrogativas previstos na Lei de Acesso à Informação, quando estabelece que os recursos contra negativa de fornecimento das informações não serão reconhecidos. Assim, com base em justificativa de que os agentes públicos, por estarem em teletrabalho e/ou quarentena, terão dificuldades para fornecer as informações, o Estado restringe a transparência no momento em que ela se torna ainda mais necessária, haja vista a decretação de calamidade realizada pelo Congresso Nacional e suas consequências sobre os atos extraordinários da administração pública, gerando, portanto, maior interesse na sua publicidade.

Outro caso que tentou dificultar o acesso à informação, nesse período de pandemia, foi o do Governo do Estado do Rio de Janeiro, em que o Subsecretário de Saúde foi afastado do cargo por colocar em sigilo processos administrativos de contratos emergenciais, realizados sem licitação, relacionados ao enfrentamento da COVID-19, que somam a quantia de 1 bilhão de reais. O sigilo foi colocado após a Folha de São Paulo revelar que uma das organizações contratadas pelo Estado possuía processos de má gestão. O referido jornal denunciou o sigilo ${ }^{26}$, fundamentando-se na Lei de Acesso à Informação e na necessidade de transparência e publicidade para o acompanhamento dos atos administrativos, principalmente no período de crise. No dia seguinte à denúncia, os documentos foram retirados do sigilo e a Secretaria de Estado e Saúde (SES) abriu sindicância para apurar o ocorrido e suas razões.

A dificuldade posta sobre a publicidade e o acesso à informação pode causar impactos que vão além da violação da garantia fundamental à informação. A falta de publicidade sobre atos de gestão pode gerar prejuízos diretos e indiretos, quando não se pode avaliar o objeto das contratações e o possível desvio de finalidade. A incidência de problemas com fraude e corrupção pode aumentar em períodos de emergência e calamidade pública, justamente pela ausência de transparência, fator que requer a atenção dos órgãos de controle, dos demais poderes e da sociedade de forma geral.

O governador do Distrito Federal, Ibaneis Rocha, chegou a declarar, em uma entrevista à imprensa, que haveria fraude e corrupção na gestão da Secretaria da Saúde da unidade federativa, durante o enfrentamento da COVID-19. Diante dessa afirmação, o Ministério Público do Distrito Federal e Territórios (MPDFT) requereu maiores informações e documentos que pudessem revelar e comprovar a situação ${ }^{27}$. O MPDFT

\footnotetext{
26 https://www1.folha.uol.com.br/cotidiano/2020/04/gestao-witzel-impoe-sigilo-em-documentos-de-contratacoes-emergenciais-de-r-1-bi-contra-coronavirus.shtml. Acesso em: 12 abr. 2020.

27 Ministério Público requisita informações ao governador do DF sobre atos de corrupção na Saúde. Disponível em: https://www. mpdft.mp.br/portal/index.php/comunicacao-menu/sala-de-imprensa/noticias/noticias-2020/11656-ministerio-publico-requisitainformacoes-ao-governador-do-df-sobre-atos-de-corrupcao-na-saude. Acesso em: 15 abr. 2020.
} 
criou a força-tarefa para a COVID-19, instruída pela Portaria PGJ n. ${ }^{\circ} 220$ de 23 de março de 2020, para acompanhar as ações adotadas no Distrito Federal, no enfrentamento da pandemia. A força-tarefa, além do acompanhamento e controle dos atos da gestão, atua em diversas áreas de interesse público e coletivo para orientar e auxiliar a sociedade, requisitando, por exemplo, a elaboração de planos de prevenção para pessoas com deficiência, bem como informações sobre aumento de gastos com publicidade ${ }^{28}$.

Em nível federal, o Tribunal de Contas da União (TCU) também apresenta um plano de acompanhamento das ações para o combate à pandemia, denominado "Plano Especial de Acompanhamento das Ações de Combate à COVID-19"29. O Plano prevê a realização de um trabalho de acompanhamento e controle dos atos da gestão pública federal para o enfrentamento da pandemia, com foco na prevenção de falhas, fraudes e desvios dos recursos públicos, destinados à situação emergencial. A proposta é fiscalizar e identificar, ainda nas fases iniciais das contratações de serviços e aquisição de insumos, situações que não estejam em conformidade e que possam acarretar problemas e prejuízos, que dificultem o alcance da efetividade das medidas propostas pelo ente público.

O trabalho realizado pelos órgãos de controle, demais poderes, entidades e instituições ligadas à sociedade civil é de vital importância para que os resultados no enfrentamento da crise sejam positivos. No entanto, a garantia da publicidade, transparência e do acesso aos dados e informações é fundamental para que esse trabalho possa ser construído de forma efetiva e que seja perene. É importante salientar que a atividade de controle deve sempre existir, estando ou não em situações de crise. Em situações como esta de pandemia, em que se faz necessário um certo grau de afrouxamento ou mitigação de algumas regras, abre-se margem ao aumento dos riscos que, por sua vez, cria a necessidade de ampliação da fiscalização e controle.

Nos casos apresentados anteriormente, para cada situação constatada de risco, ainda que não coordenada, houve uma resposta de controle. Foi possível verificar entidades, de diferentes âmbitos e setores, atuando na fiscalização e monitoramento das ações da gestão pública, durante o período de emergência sanitária. Isso demonstra que alguns mecanismos estão funcionando, ainda que não atuem de forma coordenada.

Por outro lado, verifica-se certa "ausência" de um procedimento maior e organizado de controle, de maneira a dar forma a um sistema de governança, que respalde e oriente outras instituições, para garantir que todos ou uma quantidade maior de atos públicos sejam monitorados. Muitas das ações mapeadas partiram de denúncias ou de provocação externa para que as questões e irregularidades fossem devidamente apuradas, situação que demonstra clara necessidade de instrumentalização interna e efetiva da atuação dos gestores públicos, para criar e fortalecer sistemas de vigilância e controle dos próprios atos.

\section{Compliance na gestão pública: importância do fortalecimento e coordenação das medidas de controle em período de emergência e calamidade para evitar corrupção}

A corrupção é um problema transnacional, que não possui fronteiras ${ }^{30}$ e que envolve questões sociais, econômicas e políticas, assim como temas ambientais e de direitos humanos. A luta contra a corrupção demanda esforços conjuntos no seu enfrentamento. Estados, Organizações Internacionais (OIs) e sociedade civil se empenham no desenvolvimento de normas, ferramentas e mecanismos que contribuam para o esta-

\footnotetext{
28 MPDFT. Força-tarefa Covid-19. Disponível em: https://www.mpdft.mp.br/portal/index.php/forca-tarefa-covid-19. Acesso em: 17 abr. 2020.

29 BRASIL. TCU. Tribunal de Contas da União. Plano de Acompanbamento das Ações de Combate à COVID-19 estimula o controle preventivo. 2020. Disponível em: https://portal.tcu.gov.br/imprensa/noticias/plano-de-acompanhamento-das-acoes-de-combate-a-covid19-estimula-o-controle-preventivo.htm. Acesso em 17 abr. 2020.

30 KOCHI, Shigeru. Diseñando convenciones para combatir la corrupción: La OCDE y La OEA a través de la teoría de las Relaciones Internacionales. América Latina Hoy, v. 31, 2002.
} 
belecimento de uma certa governança global ${ }^{31}$ para o combate à corrupção.

A Foreign Corrupt Practices Act (FCPA), de 1977, norma americana sobre corrupção, é considerada como um marco regulatório e referência internacional sobre a temática ${ }^{32}$, prevendo, inclusive, a possibilidade de responsabilização extraterritorial para crimes de fraude e corrupção praticados por empresas ${ }^{33}$. A partir da FCPA, surgiram diversas outras normas (vinculantes e voluntárias), bem como acordos internacionais ${ }^{34}$, que buscam contribuir para a luta mundial contra a corrupção e diminuição dos seus efeitos nos sistemas políticos, econômicos e sociais.

A governança global, que se busca estabelecer no contexto do combate à corrupção, contempla ampla participação de atores estatais e não estatais, como ONGs, empresas, técnicos, especialistas e outras organi-

31 A concepção de Governança Global decorre da evolução dos conceitos de governo e governança. Refere-se a um mecanismo, estabelecido por diferentes atores (estatais e não estatais), para lidar com problemas comuns, problemas estes que ultrapassam as fronteiras nacionais dos Estados e que demandam ações conjuntas para seu enfrentamento GONÇALVES, Alcindo. Governança Global. In: GONÇALVES, Alcindo; COSTA, José Augusto Fontoura. Governança Global e Regimes Internacionais. São Paulo: Almedina, 2011. p. 21-36. A Governança Global se caracteriza como um exercício de diálogo e tomada de decisão em vários níveis, que define políticas e mecanismos para lidar com um determinado problema comum KINGSBURY, Benedict; KRISCH, Nico; STEWART, Richard. The emergence of global administrative law. Law and contemporary problems, v. 68, n. 3/4, p. 15-61, 2005. O processo que se estabelece no âmbito da governança global considera a cooperação e a participação ampliada como elementos chave, que buscam contribuir para o alcance de consenso sobre a adoção das regras e ferramentas para uma atuação mais eficaz LIMA, Luciana; GONÇALVES, Alcindo. Normas Socioambientais Privadas: Instrumentos para a Governança Global da Sustentabilidade. Caderno de Relações Internacionais, v. 8, n. 14, 2017.

32 LEAL, Rogério Gesta; RITT, Caroline Fockink. A lei americana Foreign Corrupt Practices Act (FCPA) e sua influência na aprovação dos marcos internacionais anticorrupção. In: SEMINÁRIO INTERNACIONAL TUTELAS À EFETIVAÇÃO DE DIREITOS INDISPONÍVEIS, 1., 2017, Porto Alegre. Coletânea do I Seminário Internacional Tutelas à Efetivação de Direitos Indisponíveis. Porto Alegre: FMP, 2017. p. 173-194.

33 LEIBOLD, Annalisa. Extraterritorial Application of the FCPA Under International Law. Willamette L. Rev., v. 51, p. 225 , 2015. DOI: http://dx.doi.org/10.2139/ssrn.2489675.

34 A Organização dos Estados Americanos (OEA), em 29 de março de 1996, aprovou a "Convenção Interamericana Contra a Corrupção", sendo considerada como "o primeiro acordo internacional do gênero" KOCHI, Shigeru. Diseñando convenciones para combatir la corrupción: La OCDE y La OEA a través de la teoría de las Relaciones Internacionales. América Latina Hoy, v. 31, 2002. Aprovada no Brasil pelo Decreto Legislativo n. ${ }^{\circ}$ 152, de 25 de junho de 2002, e promulgada pelo Decreto Presidencial n. ${ }^{\circ} 4.410$, de 7 de outubro de 2002 UNODOC. United Nations Office on Drugs and Crimes. Corrup̧ão: Marco Legal. Disponível em: https://www.unodc.org/lpo-brazil/es/corrupcao/marco-legal.html. Acesso em 22 abr. 2020. Em 1997, a Organização para a Cooperação e Desenvolvimento Econômico (OCDE) aprovou a "Convenção sobre o Combate da Corrupção de Funcionários Públicos Estrangeiros em Transações Comerciais Internacionais” (Convenção OCDE sobre suborno). Trata-se de um acordo internacional para o combate à corrupção, vinculante para os 30 países membros da OCDE, que ratificaram o acordo e cinco países não membros, Brasil, Argentina, Bulgária, Chile e Eslováquia KOCHI, Shigeru. Diseñando convenciones para combatir la corrupción: La OCDE y La OEA a través de la teoría de las Relaciones Internacionales. América Latina Hoy, v. 31, 2002. O Brasil ratificou o acordo em 15 de junho de 2000, sendo promulgada pelo Decreto Presidencial n. ${ }^{\circ} 3.678$, de 30 de novembro de 2000 BRASIL. Convenção da OCDE./Presidência, Controladoria-Geral da União - $1^{\circ}$ Edição -Brasília: CGU, 2007. Disponível em: https://repositorio. cgu.gov.br/bitstream/1/29078/20/Cartilha_OCDE_2016.pdf. Acesso em: 20 abr. 2020. A Convenção da OCDE também prevê a responsabilização extraterritorial. Neste caso, "se um Estado de origem assinou um acordo internacional que inclui extraterritorialidade, os compromissos internacionais assumidos pelo estado de origem também se aplicam ao ator não estatal” JENSEN, Nathan M.; MALESKY, Edmund J. Nonstate Actors and Compliance with International Agreements: An Empirical Analysis of the OECD Anti-Bribery Convention. International Organization, v. 72, n. 1, p. 33-69, 2018. doi:10.1017/S0020818317000443. No âmbito das Nações Unidas, em 31 de outubro de 2003, foi aprovada Convenção das Nações Unidas contra a Corrupção, sendo considerada como o principal instrumento jurídico internacional sobre corrupção, apoiada nos pilares da prevenção, integridade, eficiência do setor público e participação ampliada da sociedade civil, trazendo em seu bojo diretrizes vinculantes para 187 países, que ratificaram o documento UN. United Nations. Convention against Corruption. Disponível em: https://www.unodc.org/unodc/es/treaties/CAC/. Acesso em: 19 abr. 2020. O Brasil ratificou a Convenção através do Decreto Legislativo n. ${ }^{\circ}$ 348, de 18 de maio de 2005 e do Decreto Presidencial n. ${ }^{\circ}$ 5687, de 31 de janeiro de 2006. Vale destacar, ainda, a Lei Britânica “The The Bribery Act”, de 2010, que também tem alcance extraterritorial na responsabilização de empresas, prevendo, inclusive, indicação de adoção de programas de compliance por parte das organizações BOISTER, Neil. An introduction to transnational criminal law. Oxford: Oxford University Press, 2012. p. 96-97. Como norma voluntária, destaca-se o padrão da International Organization for Standardization (ISO): a norma "ISO 37001 : 2016 - Anti-bribery management systems - requirements with guidance for use. Trata-se de um standard destinado a orientar as organizações, de qualquer setor e tamanho, no combate ao suborno e corrupção. A norma propõe um sistema de gestão certificável, com mecanismos de avaliação e controle de riscos ISO. International Organization for Standardization. ISO 37001 - Anti-bribery management systems: Requirements with guidance for use. Disponível em: https://www.iso.org/iso-37001-anti-bribery-management.html. Acesso em: 22 abr. 2020. 
zações internacionais privadas, com o objetivo de alcançar alinhamento, capaz de oferecer resultados eficazes para a melhoria das relações público-privadas. A Convenção da OCDE contra a corrupção sinaliza para os programas de "boa governança" ${ }^{35}$ e outras medidas como a melhor forma dos países lutarem contra a corrupção ${ }^{36}$. Nesse contexto, o compliance se torna uma ferramenta capaz de contribuir para a boa governança, da qual decorre o conceito de governança corporativa ${ }^{37}$, fundamentado nos princípios da transparência, integridade, equidade, accountability ${ }^{38} \mathrm{e}$ da responsabilidade social ${ }^{39}$. A governança corporativa, apesar de não possuir uma única definição, busca tratar da forma como a organização é controlada ${ }^{40}$, possuindo amplo alcance, que vai além da concepção de gestão pura e simples. A gestão é, apenas, uma parte da governança corporativa, que envolve estrutura, cultura, políticas, estratégias e as formas pelas quais a organização lida com as partes interessadas ${ }^{41}$. Trata-se de uma ferramenta de gestão relacionada ao compliance e alinhada aos mais elevados padrões éticos e morais, que contribuem para o combate à corrupção. Os aspectos, critérios e princípios da governança corporativa podem e devem ser aplicados à gestão pública e seus órgãos. Os valores e padrões éticos de comportamento, a transparência e a devida diligência "devem permear toda uma sociedade civil" ${ }^{42}$.

No Brasil, o combate à corrupção vem tomando corpo por meio de algumas normas. No âmbito do setor privado, a Lei Federal n. ${ }^{\circ}$ 12.846, de 2013, denominada como Lei Anticorrupção, estabelece a responsabilização administrativa e civil de pessoas jurídicas por atos de suborno, praticados contra a administração pública, nacional ou estrangeira. Apesar de a Lei Anticorrupção não remeter especificamente aos programas de compliance, ela pontua sobre a necessidade de estabelecimento de mecanismos de controle de riscos e de avaliação da conformidade legal e de boa governança ${ }^{43}$. Decorrentes da Lei Anticorrupção brasileira, surgem o Decreto

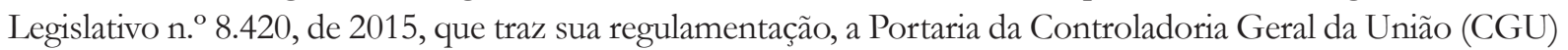
n. ${ }^{\circ}$ 910, de 2015, que estabelece procedimentos para a apuração das responsabilidades e a Portaria CGU n. ${ }^{\circ}$ 909, de 2015, que define critérios de avaliação dos programas de integridade (programas de compliance).

\footnotetext{
35 A expressão "boa governança" surge nos anos 1980, a partir dos princípios trazidos pelo Banco Mundial e Fundo Monetário Internacional (FMI), que buscaram agregar, ao conceito de governança, critérios para a avaliação da sua qualidade e eficácia GONÇALVES, Alcindo. Governança Global. In: GONÇALVES, Alcindo; COSTA, José Augusto Fontoura. Governança Global e Regimes Internacionais. São Paulo: Almedina, 2011. p. 21. Trata-se de condição atribuída à gestão e aos controles utilizados, que possuem acreditação e capacidade de demonstrar que a organização tem um bom grau de cumprimento legal DOPAZO FRAGUÍO, Pilar. La responsabilidad social corporativa (RSC) como activo facilitador de la innovación jurídica. REJIE: Revista Jurídica de Investigación e Innovación Educativa, n. 13, p. 31-48, 2016. A boa governança traz, portanto, a conotação de ação positiva, de alcance dos fins colimados e de atendimento aos compromissos assumidos LIMA, Luciana et al. Soft law como herramienta del compliance socioambiental. Revista Catalana de Dret Ambiental. (in press), 2020.

36 KOCHI, Shigeru. Diseñando convenciones para combatir la corrupción: La OCDE y La OEA a través de la teoría de las Relaciones Internacionales. América Latina Hoy, v. 31, 2002.

37 O mais utilizado conceito de Governança Corporativa remonta ao início dos anos 1990, sendo definido pelo Relatório Final do Comitê sobre Aspectos Financeiros do Governo Corporativo de 1992 (Committee Cadbury) como "o sistema pelo qual as organizações são dirigidas e controladas" CODE, Cadbury. The financial aspects of Corporate Governance. London: The Committee on the Financial Aspects of Corporate Governance and Gee and Co. Ltd, 1992. Disponível em: http://cadbury.cjbs.archios.info/_media/ files/CAD-02271.pdf. Acesso em: 22 abr. 2020. O conceito é reafirmado pela Organização para a Cooperação e Desenvolvimento Econômico (OCDE), que também entende a Governança Corporativa como o "sistema pelo qual as sociedades do setor público e privado são dirigidas e controladas" OECD. Organisation for Economic Co-operation and Development. OECD Corporate Governance Factbook, 2019. Disponível em: www.oecd.org/corporate/corporate-governance-factbook.htm. Acesso em: 20 abr. 2020. 38 HU, H.; TAN, M. Corporate governance and initial public offerings in Australia. In: ZATTONI, A.; JUDGE, W. (ed.), Corporate Governance and Initial Public Offerings: An International Perspective Cambridge: Cambridge University Press, 2012. p. $37-63$. doi:10.1017/CBO9781139061513.003.

39 A responsabilidade social é entendida como a conduta organizacional pautada na gestão diligente. Refere-se ao comportamento ético e transparente da organização preocupada com os impactos de suas decisões e atividades na sociedade ASSOCIAÇÃO BRASILEIRA DE NORMAS TÉCNICAS. ABNT. NBR ISO 26000: Diretrizes sobre responsabilidade social. Rio de Janeiro: ABNT, 2010.

40 MARQUES, Maria da Conceição da Costa. Aplicação dos princípios da governança corporativa ao sector público. Revista de Administração Contemporânea, v. 11, n. 2, p. 11-26, 2007.

41 BARRETT, Pat. Achieving better practice corporate governance in the public sector. Australian National Audit Office, 2002.

42 BENEDICTO, Samuel Carvalho de et al. Governança corporativa: uma análise da aplicabilidade dos seus conceitos na administração pública. Organizações Rurais \& Agroindustriais, v. 15, n. 2, p. 286-300, 2013.

43 MIRANDA, Wallace Vieira de; ZAGANELLI, Juliana Costa. Marco civil da internet e política pública de transparência: uma análise da e-democracia e do compliance público. Revista Brasileira de Políticas Públicas, v. 7, n. 3, p. 633-646, 2018.
} 
No âmbito da administração pública indireta, relacionado às empresas estatais, foi editada a Lei 13.303, de 2016, conhecida como Estatuto das Estatais. A norma surge para atender as Diretrizes da OCDE sobre a Governança Corporativa das Empresas Estatais, publicada em 2005 e revisada em $2015^{44}$, estabelecendo a obrigatoriedade da implementação da gestão de riscos e controles, bem como divulgação de códigos de ética, conduta e integridade corporativa pelas empresas estatais e de economia mista. Em 2019, o Governo Federal publicou a Lei 13.848/2019, conhecida como Lei das Agências Reguladoras. A norma em questão também prevê o estabelecimento de um programa de integridade corporativa, para a devida gestão e controle dos riscos da atividade e alinhamento das práticas e condutas dos órgãos reguladores, sem esquecer da obrigatoriedade de cumprimento legal de outras normas destinadas ao setor.

No caso da administração pública direta, por meio do Decreto n. ${ }^{\circ} 9.203$, de 22 de novembro de 2017, iniciou-se um processo de estabelecimento de uma política de governança no setor. Em abril de 2018, foi lançado o programa de Unidade de Gestão da Integridade (UGI) da CGU, que tem como objetivo o estabelecimento de programas de integridade por todos os órgãos e entidades da administração pública direta, autárquica e fundacional. Esse programa visa construir, por meio de um plano, caracterizado pelas normas, práticas, procedimentos, valores éticos e princípios, buscando criar no setor público um procedimento harmonizado de prevenção, identificação, avaliação, mitigação e responsabilização de fraudes e corrupção ${ }^{45}$. O referido Decreto traz sustentação à implementação de programas de integridade corporativa na administração direta, que por sua vez, possui um verdadeiro arsenal normativo implicado na temática, como as normas referentes à responsabilidade fiscal do administrador público (LRF), Lei de Improbidade Administrativa (Lei n. ${ }^{\circ}$ 8.429/92), Lei da Transparência (Lei Complementar n. ${ }^{\circ}$ 131/2009), Lei de Acesso à Informação n. ${ }^{\circ}$ 12.527/11 (LAI), dentre outras.

O Decreto Federal n. ${ }^{\circ}$ 9.203/2017 estabeleceu a política de governança da administração pública federal direta, autárquica e fundacional. A norma, por si só, pode ser considerada como importante instrumento da governança pública, que acena no sentido da definição das regras para o estabelecimento e implementação do programa de integridade da administração pública direta. Fora as normas, os diversos órgãos de controle interno e externo ${ }^{46}$, como os Tribunais de Contas, Controladorias, Procuradorias e outros órgãos de fiscalização, podem contribuir de forma essencial para a implementação do compliance na administração pública, justamente por já atuarem com as regras estabelecidas no arcabouço normativo existente e regras de conduta ética estabelecidas.

Compliance está diretamente relacionado ao cumprimento ético-normativo, bem como ao controle dos riscos ao qual tanto o setor público quanto privado estão sujeitos. Quando se fala em cumprimento normativo, pode-se questionar a redundância ou prolixidade da sua recomendação à administração pública, que está naturalmente adstrita ao princípio da legalidade. No entanto, o cumprimento abordado neste estudo vai além da conformidade legal, englobando diversos outros aspectos e elementos que extrapolam os contornos na lei. Compliance não se refere exclusivamente à adequação às normas cogentes (bard law). No âmbito da conformidade, entende-se coexistir uma estrutura de normas, padrões e ferramentas, também de natureza voluntária $(\text { soft law })^{47}$, que possam dar suporte à implementação e eficácia das diretrizes internacionalmente propostas para o combate à corrupção.

\footnotetext{
44 ORGANIZAÇÃO PARA COOPERAÇÃO E DESENVOLVIMENTO ECONÔMICO. OCDE. Diretrizes da OCDE sobre Governança Corporativa de Empresas Estatais. Paris: OCDE Publishing, 2015. Disponível em: https://doi.org/10.1787/9789264181106pt. Acesso em: 25 abr. 2020.

45 BRASIL. Ministério da Transparência e Controladoria-Geral da União. Guia prático das Unidades de Gestão da Integridade: Orientações para a instituição, aperfeiçoamento e uniformização nos órgãos e entidades da administração pública federal direta, autárquica e fundacional. Brasília, 2019. Disponível em: https://www.gov.br/cgu/pt-br/centrais-de-conteudo/publicacoes/etica-eintegridade/arquivos/unidades-de-gestao.pdf. Acesso em: 25 abr. 2020.

46 PONDÉ, Lafayette. Controle dos atos da administração pública. Revista de Direito Administrativo, v. 212, p. 41-47, 1998.

47 Soft law é o termo dado a normas de natureza não cogente, que pode incluir diretrizes, recomendações, princípios, declarações, códigos de conduta, entre outros, com duração permanente ou por tempo determinado, servindo, neste caso, a uma específica finalidade, podendo, ainda, compor normas legais (hard law) e inspirar atividade legislativa.
} 
No âmbito da administração pública, o compliance está essencialmente relacionado à transparência e ao dever de prestar contas. A transparência é um princípio de extrema importância para o direito administrativo nacional e global ${ }^{48}$, em razão da necessidade cada vez maior de alinhamento dos atos da gestão pública, com as práticas internacionais relacionadas à contratação pública, que demandam cada vez mais transparência, integridade e prestação de contas, pressupostos importantes para a gestão eficiente e relação segura entre as partes interessadas. A governança global sobre o combate à corrupção se estrutura na transparência, considerada como "pressuposto básico de governabilidade em respeito ao cidadão e às próprias instituições do Estado"49. A transparência permite intercâmbio de informações, fortalecimento das instituições e da democracia, bem como a melhoria da credibilidade do ator estatal perante seus pares.

As atividades, sejam elas públicas ou privadas, possuem suas especificidades e, consequentemente, estão expostas a diferentes riscos, que devem ser tratados conforme a probabilidade de ocorrência e nível de impacto à atividade. Nesse sentido, a harmonização das regras e uniformização dos mecanismos e ferramentas de controle e de tratamento de riscos, também se tornam necessárias ao setor público. Primeiramente, porque a atividade pública se expõe a riscos não contemplados por normas legais, apresentando a necessidade de valoração e tratamento desses riscos, diante da possibilidade de consequências gravosas para a sociedade e para a própria administração. Segundo, porque o não cumprimento legal também é um risco que deve ser considerado pela gestão pública, devendo ser tratado como qualquer outro que cause os mesmos impactos. Além disso, a administração pública, que também se relaciona com o ente privado, necessita estar alinhada e comprometida com os padrões internacionais de combate à corrupção, devendo, portanto, estabelecer uma boa governança, que contemple efetivos controles internos e externos para tratar os riscos inerentes a essa relação.

Nesse sentido, o conceito de governança corporativa, apoiada na conformidade, pode e deve ser aplicado à gestão pública, de forma a permitir a instrumentalização mais eficiente do gerenciamento das decisões e da prestação de contas, contemplando, ainda, a ampliação da participação de outros atores no seu processo ${ }^{50}$. A boa governança no setor público, para além do uso eficiente dos recursos, deve proporcionar a adequação e coordenação dos procedimentos e regras, bem como melhor distribuição e mapeamento das responsabilidades e controle de riscos, que possam ocasionar problemas, como desvios, fraudes e corrupção.

A aplicação do compliance no setor público é importante para organizar e dar maiores condições de controle e monitoramento das ações e decisões tomadas, que devem ser pautadas pela legalidade, sem esquecer a ética, transparência e prestação de contas. Accountability e transparência ${ }^{51}$ são os principais nortes para a indicação dos critérios da governança corporativa ao setor público, âmbito em que as estruturas de gestão se distinguem da governança privada, em razão da existência de outros meios de controle inerentes à divisão política de poderes, que cria o sistema de freios e contrapesos ${ }^{52}$ e demais "sistemas de valores, que enfatizam noções de ética e códigos de conduta com base legislativa" "53. A boa governança do setor público se demons-

\footnotetext{
48 Direito Administrativo Global (DAG) DA SILVA, Alice Rocha; SANTOS, Ruth MP. A influência do direito administrativo global no processo brasileiro de contratação pública à luz do princípio da transparência. Revista Brasileira de Políticas Públicas, v. 6, n. 2, p. 66-88, 2016).

${ }_{49}$ SILVA, Alice Rocha da; SANTOS, Ruth MP. A influência do direito administrativo global no processo brasileiro de contratação pública à luz do princípio da transparência. Revista Brasileira de Políticas Públicas, v. 6, n. 2, p. 66-88, 2016.

50 BHATTA, Gambhir. International dictionary of public management and governance. New York: Routledge, 2015.

51 BRASIL. Tribunal de Contas da União. Referencial de combate a fraude e corrup̧̧ão: aplicável a órgãos e entidades da Administração Pública. Brasília: TCU, Coordenação-Geral de Controle Externo dos Serviços Essenciais ao Estado e das Regiões Sul e CentroOeste (Coestado), Secretaria de Métodos e Suporte ao Controle Externo (Semec), 2a Edição, 2018. 148 p. Disponível em: https:// portal.tcu.gov.br/biblioteca-digital/referencial-de-combate-a-fraude-e-corrupcao.htm. Acesso em: 25 abr. 2020.

52 O sistema de freios e contrapesos surge a partir da teoria da separação de poderes de Montesquieu, descrita na obra Espírito das Leis. A Constituição Federal do Brasil, de 1988, em seu Art. $2^{\circ}$ prevê a separação de poderes Executivo, Legislativo e Judiciário que, apesar de independentes, exercem papel mútuo de controle dos atos praticados, devendo sempre "andar em concerto" MONTESQUIEU, Charles de Secondat, Baron de. O Espírito das Leis: as formas de governo, a federação, a divisão dos poderes. 9. ed. São Paulo: Saraiva, 2008. p. 28-30.

53 BARRETT, Pat. Achieving better practice corporate governance in the public sector. Australian National Audit Office, 2002.
} 
tra, dessa forma, como a base para um desempenho organizacional eficaz e sustentado. Assim como no setor privado, a governança pública deve ser apoiada pela liderança e por uma cultura organizacional ${ }^{54}$, alinhada com a atividade desenvolvida, sempre em conformidade com os princípios e normas preestabelecidos.

O processo de implementação de compliance na administração pública apresenta limitações, como a complexidade do sistema, em razão da sua estrutura e divisões internas, que podem criar obstáculos burocráticos na obtenção das informações a serem conectadas. No entanto, um elemento facilitador a ser considerado para essa questão é a crescente interconectividade ${ }^{55}$, cada vez maior, das informações, facilitada pelo avanço tecnológico e seus instrumentos, que podem contribuir para a harmonia dos procedimentos ${ }^{56}$, permitindo que o setor possa construir uma mesma linguagem sobre política, conduta ética e padrões de comportamento, ampliando e democratizando o acesso às informações e dados.

Outra possível limitação é a ausência de apoio e comprometimento da alta administração com o compliance e suas estruturas. O compromisso da alta administração é um dos pilares do programa de integridade, elemento importante para fortalecer a cultura ética, por meio do empenho, do exemplo e da própria função de direção exercida. É a alta administração que dá o tom, ou seja, o tom no topo (tone at the top $)^{57}$. O comportamento ético e engajamento deve partir da liderança, que deve orientar e incentivar o cumprimento das normas e códigos de conduta dentro da organização, sob pena de não obter resultados eficazes ${ }^{58}$.

O ponto nevrálgico da questão é que o compliance, bem estruturado, harmonizado com os demais meios e regras gerais de controle, torna-se um valioso instrumento para garantir a lisura das ações e decisões tomadas, mesmo em situações de crise e emergências. Isso se dá porque, ainda que haja necessidade de flexibilização de algumas regras, procedimentos ou normas, com o intuito de facilitar a atuação do ente público e seus órgãos, no enfrentamento de problemas graves, como no caso da pandemia da COVID-19, os controles internos e externos funcionarão para assegurar o mapeamento e gerenciamento das fragilidades.

Importante frisar que o que se flexibiliza, em situações emergenciais, são determinadas regras e procedimentos para o atendimento de uma finalidade pública ainda maior. No entanto, não há e não deverá haver qualquer flexibilização dos princípios de transparência e publicidade, sob pena de se abrir mão de meios de controle importantes para a prestação de contas e para a manutenção do dever ético e de boa conduta do ente público, que devem existir em qualquer circunstância. Ademais, as exceções precisam ser vistas como riscos, que necessitam de mapeamento e tratamento adequado, de forma a reduzir impactos.

A existência de efetivo e legítimo controle das atividades públicas garante a participação de diferentes atores no processo de governança que, por meio da cooperação e da coordenação dos diversos interesses, auxiliam a "formação de um espaço público que, baseado na negociação e consenso, atribui maior grau de legitimidade, transparência, racionalidade e eficiência à persecução dos fins sociais" ${ }^{59}$.

Dessa forma, A implementação pela administração pública de ferramentas de controle efetivas, perenes e alinhadas com as principais normas internacionais, demonstra compromisso do Estado com a governança global, que vem se estabelecendo no âmbito da luta contra a corrupção, fato que poderá gerar outros benefícios ao país, por oferecer maior segurança jurídica, política e econômica a investimentos externos.

\footnotetext{
54 IFAC, PSC. Study 13-Governance in the Public Sector: A Governing Body Perspective. New York, 2001. Disponível em: https:// www.ifac.org/system/files/publications/files/study-13-governance-in-th.pdf. Acesso em: 21 abr. 2020.

55 BARRETT, Pat. Achieving better practice corporate governance in the public sector. Australian National Audit Office, 2002.

56 MIRANDA, Wallace Vieira de; ZAGANELLI, Juliana Costa. Marco civil da internet e política pública de transparência: uma análise da e-democracia e do compliance público. Revista Brasileira de Políticas Públicas, v. 7, n. 3, p. 633-646, 2018.

57 SCHWARTZ, Mark S.; DUNFEE, Thomas W.; KLINE, Michael J. Tone at the top: An ethics code for directors?. Journal of Business Ethics, v. 58, n. 1-3, p. 79, 2005.

58 COIMBRA, Marcelo de Aguiar; MANZI, Vanessa Alessi (coord.). Manual de compliance: preservando a boa governança e a integridade das organizações. São Paulo: Atlas, 2010. p.26-28.

59 MOURA, Emerson Affonso da Costa. Transparência administrativa, lei federal n. ${ }^{\circ}$ 12.527/2011 e sigilo dos documentos públicos: a inconstitucionalidade das restrições ao acesso à informação. Brazilian Journal of Public Policy, v. 6, n. 2, p. $37,2016$.
} 


\section{Considerações finais}

O controle e constante monitoramento da conformidade legal são elementos importantes a qualquer setor, seja ele público ou privado, para que se possam avaliar as decisões, processos e eficácia das medidas implementadas na gestão. Mesmo em situações de crise, programas de integridade permitem a identificação e consequente redução de condutas ilícitas ou que fujam dos padrões éticos e morais estabelecidos. Os impactos da ausência de transparência e publicidade dos atos de gestão poderão ser tão maléficos para a sociedade quanto a situação de emergência que dê causa à suspensão de normas e procedimentos vigentes. Limitar o acesso à informação, ainda que por razões justificáveis, não deve ser tida como uma opção plausível, tendo em vista o outro lado da questão, ou seja, a necessidade patente de transparência para garantir a eficiência e probidade dos atos realizados nesse período.

Apesar de a administração pública possuir diversos outros mecanismos e órgãos de controle, faz-se necessária a implementação de regras harmonizadas globalmente e que possam garantir que os riscos estejam de fato sendo identificados e controlados. Não basta, apenas, dizer que a administração pública está adstrita ao Princípio da Legalidade e que possui, em sua estrutura, mecanismos de controle e transparência. Faz-se necessário que a alta administração pública apoie e valide a implementação de programas de integridade e que estes sejam viabilizados e aplicados em todos os órgãos, de forma coesa e integral.

Conclui-se, então, pela indicação da aplicabilidade de programas de integridade na administração direta, por ser um mecanismo de controle adaptável a sistemas públicos e privados e difundido mundialmente, por sua condição de alinhamento com normas internacionais consagradas de boa governança. A aplicação de programas de integridade na administração pública direta é capaz de favorecer a manutenção dos mecanismos de vigilância já existentes e de trazer novos controles, harmonizando-os sistematicamente e permitindo que funcionem com eficácia, mesmo em situações que requeiram mitigação dos efeitos de outras normas e procedimentos, como no caso das regras de contratações públicas em momentos de emergência e calamidade pública. A implementação e fortalecimento das estruturas de compliance na administração pública direta é importante porque elas surgem como ferramentas que permitem o alinhamento do setor com as mais atuais normas globais, que atuam na luta contra a corrupção e contribuem para a redução sistemática da cultura de fraudes e suborno, que atingem a administração pública. O sistema permite a manutenção da transparência e accountability, regras que não podem e não devem sofrer flexibilização.

Compreende-se que a atuação pública demanda constante e sustentado alinhamento com as regras globais de conformidade e integridade para a adoção de mecanismos e procedimentos, que possam garantir uma boa governança pública, transparente, eficiente e empenhada na gestão dos riscos e controles inerentes, com a finalidade de evitar fraudes e corrupção, que tanto prejudicam o interesse público e a sociedade de forma geral.

\section{Referências}

ALI, Shajeea Arshad et al. The outbreak of Coronavirus Disease 2019 (COVID-19)_An emerging global health threat. Journal of Infection and Public Health, 2020.

ASSOCIAÇÃO BRASILEIRA DE NORMAS TÉCNICAS. ABNT. NBR ISO 26000: Diretrizes sobre responsabilidade social. Rio de Janeiro: ABNT, 2010.

ATAÍDE, Pedro. A (im) possibilidade de medida provisória na regulamentação de atividade minerária. Unisul de Fato e de Direito: Revista Jurídica da Universidade do Sul de Santa Catarina, v. 9, n. 16, p. 37-46, 2018.

BARRETT, Pat. Achieving better practice corporate governance in the public sector. Australian National Audit Office, 
2002.

BENEDICTO, Samuel Carvalho de et al. Governança corporativa: uma análise da aplicabilidade dos seus conceitos na administração pública. Organizações Rurais \& Agroindustriais, v. 15, n. 2, p. 286-300, 2013.

BHATTA, Gambhir. International dictionary of public management and governance. New York: Routledge, 2015.

BOISTER, Neil. An introduction to transnational criminal law. Oxford: Oxford University Press, 2012.

BRASIL. Convenção da OCDE./Presidência, Controladoria-Geral da União - $1^{\circ}$ Edição -Brasília: CGU, 2007. Disponível em: https://repositorio.cgu.gov.br/bitstream/1/29078/20/Cartilha_OCDE_2016.pdf. Acesso em: 20 abr. 2020.

BRASIL. Ministério da Transparência e Controladoria-Geral da União. Guia prático das Unidades de Gestão da Integridade: Orientações para a instituição, aperfeiçoamento e uniformização nos órgãos e entidades da administração pública federal direta, autárquica e fundacional. Brasília, 2019. Disponível em: https://www. gov.br/cgu/pt-br/centrais-de-conteudo/publicacoes/etica-e-integridade/arquivos/unidades-de-gestao. pdf. Acesso em: 25 abr. 2020.

BRASIL. Tribunal de Contas da União. Referencial de combate a fraude e corrupscão: aplicável a órgãos e entidades da Administração Pública. Brasília: TCU, Coordenação-Geral de Controle Externo dos Serviços Essenciais ao Estado e das Regiões Sul e Centro-Oeste (Coestado), Secretaria de Métodos e Suporte ao Controle Externo (Semec), 2a Edição, 2018. 148 p. Disponível em: https://portal.tcu.gov.br/biblioteca-digital/referencial-de-combate-a-fraude-e-corrupcao.htm. Acesso em: 25 abr. 2020.

CODE, Cadbury. The financial aspects of Corporate Governance. London: The Committee on the Financial Aspects of Corporate Governance and Gee and Co. Ltd, 1992. Disponível em: http://cadbury.cjbs.archios.info/_media/ files/CAD-02271.pdf. Acesso em: 22 abr. 2020.

COIMBRA, Marcelo de Aguiar; MANZI, Vanessa Alessi (coord.). Manual de compliance: preservando a boa governança e a integridade das organizações. São Paulo: Atlas, 2010.

DI PIETRO, Maria Sylvia Zanella. Direito administrativo. 26. ed. São Paulo: Atlas, 2013.

DOMINGUEZ, Bruno. Alerta global: novo coronavírus é a sexta emergência em saúde pública de importância internacional declarada pela OMS. RADIS: Comunicaşão e Saúde, n. 210, p. 14-21, 2020.

DOPAZO FRAGUÍO, Pilar. La responsabilidad social corporativa (RSC) como activo facilitador de la innovación jurídica. REJIE: Revista Jurídica de Investigación e Innovación Educativa, n. 13, p. 31-48, 2016.

FREITAS, Carlos Machado de et al. Fortalecimento das capacidades de prontidão e resposta frente a situações de emergência de interesse de saúde pública: Região Nordeste. Rio de Janeiro: CEPEDES/FIOCRUZ, 2013. 34 p. Relatório de pesquisa, 2013.

GONÇALVES, Alcindo. Governança Global. In: GONÇALVES, Alcindo; COSTA, José Augusto Fontoura. Governança Global e Regimes Internacionais. São Paulo: Almedina, 2011.

HU, H.; TAN, M. Corporate governance and initial public offerings in Australia. In: ZATTONI, A.; JUDGE, W. (ed.), Corporate Governance and Initial Public Offerings: An International Perspective Cambridge: Cambridge University Press, 2012. p. 37-63. doi:10.1017/CBO9781139061513.003.

IFAC, PSC. Study 13-Governance in the Public Sector: A Governing Body Perspective. New York, 2001. Disponível em: https://www.ifac.org/system/files/publications/files/study-13-governance-in-th.pdf. Acesso em: 21 abr. 2020.

INTERNATIONAL ORGANIZATION FOR STANDARDIZATION. ISO. ISO 37001 - Anti-bribery management systems: Requirements with guidance for use. Disponível em: https://www.iso.org/iso-37001-anti-bribery-management.html. Acesso em: 22 abr. 2020. 
JENSEN, Nathan M.; MALESKY, Edmund J. Nonstate Actors and Compliance with International Agreements: An Empirical Analysis of the OECD Anti-Bribery Convention. International Organization, v. 72, n. 1, p. 33-69, 2018. doi:10.1017/S0020818317000443.

KHAIR, Amir Antônio. Lei de responsabilidade fiscal: guia de orientação para as prefeituras. Brasília: Ministério do Planejamento, Orçamento e Gestão; BNDES, 2000.

KINGSBURY, Benedict; KRISCH, Nico; STEWART, Richard. The emergence of global administrative law. Law and contemporary problems, v. 68, n. 3/4, p. 15-61, 2005.

KOCHI, Shigeru. Diseñando convenciones para combatir la corrupción: La OCDE y La OEA a través de la teoría de las Relaciones Internacionales. América Latina Hoy, v. 31, 2002.

LAI, Chih-Cheng et al. Severe acute respiratory syndrome coronavirus 2 (SARS-CoV-2) and corona virus disease-2019 (COVID-19): the epidemic and the challenges. International journal of antimicrobial agents, 2020.

LEAL, Rogério Gesta; RITT, Caroline Fockink. A lei americana Foreign Corrupt Practices Act (FCPA) e sua influência na aprovação dos marcos internacionais anticorrupção. In: SEMINÁRIO INTERNACIONAL TUTELAS À EFETIVAçÃO DE DIREITOS INDISPONÍVEIS, 1., 2017, Porto Alegre. Coletânea do I Seminário Internacional Tutelasà Efetivação de Direitos Indisponiveis. Porto Alegre: FMP, 2017. p. 173-194.

LEIBOLD, Annalisa. Extraterritorial Application of the FCPA Under International Law. Willamette L. Rev., v. 51, p. 225, 2015. DOI: http://dx.doi.org/10.2139/ssrn.2489675.

LEITE FILHO, Geraldo Alemandro; COLARES, André Felipe Vieira; ANDRADE, Izabela Cristina Fonseca. Transparência da gestão fiscal pública: um estudo a partir dos portais eletrônicos dos maiores municípios do Estado de Minas Gerais. Contabilidade Vista \& Revista, v. 26, n. 2, p. 114-136, 2015.

LIMA, Luciana et al. Soft law como herramienta del compliance socioambiental. Revista Catalana de Dret Ambiental. (in press), 2020.

LIMA, Luciana; GONÇALVES, Alcindo. Normas Socioambientais Privadas: Instrumentos para a Governança Global da Sustentabilidade. Caderno de Relações Internacionais, v. 8, n. 14, 2017.

LÓPEZ, Verónica et al. Recommendations on management of the SARS-CoV-2 coronavirus pandemic (Covid-19) in kidney transplant patients. Nefrología (English Edition), in press, 2020.

MACEDO JÚNIOR, Adriano Menino de. COVID-19: calamidade pública. Medicus, v. 2, n. 1, p. 1-6, 2020.

MATTOS, Mauro Roberto Gomes de. Licitação e a Lei de Responsabilidade Fiscal. Revista de Direito Administrativo, Rio de Janeiro, v. 230, p. 357-388, out. 2002.

MEDEIROS, Katia Rejane de et al. Lei de Responsabilidade Fiscal e as despesas com pessoal da saúde: uma análise da condição dos municípios brasileiros no período de 2004 a 2009. Ciência \& Saúde Coletiva, v. 22, p. 1759-1769, 2017.

MIRANDA, Wallace Vieira de; ZAGANELLI, Juliana Costa. Marco civil da internet e política pública de transparência: uma análise da e-democracia e do compliance público. Revista Brasileira de Políticas Públicas, v. 7, n. 3, p. 633-646, 2018.

MONTESQUIEU, Charles de Secondat, Baron de. O Espirito das Leis: as formas de governo, a federação, a divisão dos poderes. 9. ed. São Paulo: Saraiva, 2008.

MOURA, Emerson Affonso da Costa. Transparência administrativa, lei federal n. ${ }^{\circ}$ 12.527/2011 e sigilo dos documentos públicos: a inconstitucionalidade das restrições ao acesso à informação. Brażilian Journal of Public Policy, v. 6, n. 2, p. 37, 2016. 
ORGANIZAÇÃO PARA COOPERAÇÃO E DESENVOLVIMENTO ECONÔMICO. OCDE. Diretrizes da OCDE sobre Governança Corporativa de Empresas Estatais. Paris: OCDE Publishing, 2015. Disponível em: https://doi.org/10.1787/9789264181106-pt. Acesso em: 25 abr. 2020.

PONDÉ, Lafayette. Controle dos atos da administração pública. Revista de Direito Administrativo, v. 212, p. 41-47, 1998.

QUINTÃO, Vinicius, et al. O Anestesiologista e a COVID-19. Brazilian Journal of Anesthesiology, in press. 2020.

SALES, Tainah. Aspectos Jurídicos Do Impeachment, Dos Crimes De Responsabilidade E Das "Pedaladas Fiscais". Revista de Direito Brasileira, v. 16, n. 7, p. 57-78, 2017.

SCHWARTZ, Mark S.; DUNFEE, Thomas W.; KLINE, Michael J. Tone at the top: An ethics code for directors?. Journal of Business Ethics, v. 58, n. 1-3, p. 79, 2005.

SERRANO, Pedro Estevam Alves Pinto. Dos requisitos jurídicos para a instauração do processo de impeachment do Presidente da República. Revista de Investigações Constitucionais, v. 2, n. 2, p. 189-213, 2015.

SHAW, Rajib; KIM, Yong-kyun; HUA, Jinling. Governance, technology and citizen behavior in pandemic: Lessons from COVID-19 in East Asia. Progress in Disaster Science, p. 100090, 2020.

SILVA, Alice Rocha da; SANTOS, Ruth MP. A influência do direito administrativo global no processo brasileiro de contratação pública à luz do princípio da transparência. Revista Brasileira de Políticas Públicas, v. 6, n. 2, p. 66-88, 2016.

TEIJEIRA RODRÍGUEZ, Mariano. Responsabilidad social corporativa y compliance legal (autorregulación y control interno). In: DERECHO administrativo del medio ambiente: Temas y prácticas de actualidad jurídica. Servicio de Publicaciones de la Facultad de Derecho, 2018. p. 219-240

UNITED NATIONS OFFICE ON DRUGS AND CRIMES. UNODOC. Corrupcãa: Marco Legal. Disponível em: https://www.unodc.org/lpo-brazil/es/corrupcao/marco-legal.html. Acesso em: 22 abr. 2020.

UNITED NATIONS. UN. Convention against Corruption. Disponível em: https://www.unodc.org/unodc/ es/treaties/CAC/. Acesso em: 19 abr. 2020.

WHO. WHO Timeline - COVID-19. 2020. Disponível em: https://www.who.int/news-room/detail/08-04-2020-who-timeline---COVID-19. Acesso em: 10 abr. 2020.

WHO. World Health Organization et al. Reglamento sanitario internacional. 2a edición. Ginebra: Organización Mundial de la Salud, 2008. Disponível em: https://apps.who.int/iris/bitstream/handle/10665/43983/9789243580418_spa.pdf?sequence=1. Acesso em: 13 abr. 2020. 
Para publicar na revista Brasileira de Políticas Públicas, acesse o endereço eletrônico www.rbpp.uniceub.br

Observe as normas de publicação, para facilitar e agilizar o trabalho de edição. 